\title{
HUBUNGAN TINGKAT PENGETAHUAN TENTANG KANKER SERVIKS DENGAN SIKAP TERHADAP PEMERIKSAAN PAP SMEAR PADA WUS DI DUSUN PANCURAN BANTUL TAHUN 2017
}

\author{
Amalia Ratna Kusumaningrum*, Siti Tyastuti, Hesty Widyasih \\ Jurusan Kebidanan Poltekkes Kemenkes Yogyakarta \\ E-mail: amaliaratnak@gmail.com
}

\begin{abstract}
In Indonesia, the highest prevalence of cervical cancer is located in D.I Yogyakarta. Low knowledge of cervical cancer becomes one of the factors causing high incidence of cervical cancer. Cervical cancer can be prevented by using Pap smear early on. Coverage of Pap smear can be used below $10 \%$. Good knowledge also can support Pap smear. The purpose of this study is to know the correlation between knowledge level on cervical cancer and attitude toward Pap smear on women at fertile age in Pancuran, Bantul, 2017. The population was 191 women's fertile age at Pancuran village, Bantul. This study used cross sectional study design with simple random sampling technique. The sample of this study was 90 participants. The data collection used the questionnaire on the level of knowledge and the attitude on April 16, 23, and 27, 2017. Data analysis used Chi-Square test. The result of the study shows $80 \%$ of the sample was elementary, economic status was $69 \%$ below Bantul minimum wage, $82 \%$ had not done Pap smear test before, $48 \%$ with good knowledge, and $39 \%$ the attitude was supporting Pap smear. The result of statistical test showed p-value 0.000 , with the power was moderate (0.504). This study concludes that there is a correlation between the level of knowledge and the attitude toward Pap smear test which the value is moderate.
\end{abstract}

Keywords : Knowledge, Attitude, Cervical Cancer, Pap Smear

\section{ABSTRAK}

Prevalensi kanker serviks tertinggi di Indonesia berada di Provinsi D.I Yogyakarta. Rendahnya pengetahuan mengenai kanker serviks secara umum berhubungan dengan masih tingginya angka kejadian kanker serviks. Kanker serviks merupakan salah satu kanker yang dapat dicegah sejak dini dengan pap smear. Cakupan pap smear masih $<10 \%$. Pengetahuan yang baik akan membentuk sikap yang mendukung pula untuk pap smear. Tujuan dalam penelitian ini adalah diketahuinya keeratan hubungan tingkat pengetahuan tentang kanker serviks dengan sikap terhadap pemeriksaan pap smear pada WUS Di Dusun Pancuran, Bantul tahun 2017. Penelitian ini menggunakan desain Cross Sectional study. Populasi nya adalah WUS Di Dusun Pancuran berjumlah 191 orang dengan teknik pengambilan sampel menggunakan simple random sampling. Sampel dalam penelitian ini sebanyak 90 responden. Pengambilan data menggunakan kuesioner tingkat pengetahuan dan kuesioner sikap, pada tanggal 16, 23, dan 27 April 2017. Analisis data menggunakan uji ChiSquare test. Hasil penelitian menunjukkan $80 \%$ responden berpendidikan dasar (SD/SMP), status ekonomi $69 \%<$ UMK Bantul, pengalaman $82 \%$ belum pernah melakukan pemeriksaan pap smear, $48 \%$ berpengetahuan baik, dan $39 \%$ bersikap mendukung. Hasil uji statistik menunjukkan nilai p-value 0.000 , dengan keeratan hubungan sedang (0.504). Kesimpulan penelitian ini terdapat hubungan antara tingkat pengetahuan tentang kanker serviks dengan sikap terhadap pemeriksaan pap smear dengan keeratan hubungan sedang.

Kata Kunci : Pengetahuan, Sikap, Kanker Serviks, Pap Smear

\section{PENDAHULUAN}

Kanker leher rahim (kanker serviks) adalah kanker yang banyak ditemukan pada wanita di negara berkembang. Indonesia termasuk negara berkembang yang setiap tahun tidak kurang dari 170.000 kasus kanker serviks terjadi, dan menjadikan sebagai pembunuh nomor 2 di Indonesia'.

Riset Kesehatan Dasar (Riskesdas) melaporkan prevalensi kanker serviks tertinggi berada di Provinsi D.I Yogyakarta yaitu sebesar $1,5 \%{ }^{2}$. Selain itu data dari dinas kesehatan Provinsi D.I Yogyakarta angka kejadian kanker serviks pada Kota Yogyakarta sebanyak 341 kasus, di Kabupaten Sleman sebanyak 962 kasus, di Kabupaten Gunungkidul sebanyak 105 kasus, di Kabupaten Kulonprogo sebanyak 205 kasus, dan terbanyak berada di Kabupaten Bantul sebanyak 1355 kasus $^{3}$.

Informasi mengenai kanker serviks masih kurang dipahami oleh sebagian besar wanita usia subur (WUS) di Indonesia. Rendahnya pengetahuan mengenai kanker serviks secara umum berhubungan dengan masih tingginya angka kejadian kanker serviks. Hal ini sangat memprihatinkan mengingat kanker serviks merupakan salah satu kanker yang 
dapat dicegah sejak dini dengan deteksi dini salah satunya adalah pap smear ${ }^{4}$.

Di Desa Terong, Bantul latar belakang pendidikan perempuannya mempunyai proporsi terbanyak yaitu tamatan SD sebesar $32 \%{ }^{5}$. Belum optimalnya penggunaan pap smear sebagai sarana untuk deteksi dini juga yang menjadi masalah hingga sekarang. Cakupan pap smear diseluruh dusun di Desa Terong terjadi merata yaitu $<10 \%$, padahal cakupan yang efektif dalam menurunkan angka kesakitan dan angka kematian karena kanker serviks adalah $80 \%{ }^{3}$. Menurut hasil studi pendahuluan di Dusun Pancuran, Terong, Bantul sendiri mempunyai pasangan usia subur (PUS) yang terbanyak dibanding dusun yang lain.

Faktor-faktor yang mempengaruhi pengetahuan salah satunya yaitu pendidikan, pengalaman, dan status ekonomi ${ }^{6}$. Seseorang setelah mengetahui sesuatu objek, lalu mengorganisasikan dan menginterprestasikan berbagai macam informasi yang ia terima, dan setelah tahu, proses selanjutnya mereka kemudian bersikap terhadap objek tersebut. Faktor pembentukan sikap sendiri salah satunya yaitu dipengaruhi oleh pengetahuan. Pengetahuan seseorang berhubungan dengan sikap terhadap sesuatu objek, dengan pengetahuan yang baik, akan membentuk sikap yang mendukung pula dan diharapkan dapat terwujud dalam tindakan nyata untuk pap smear ${ }^{7}$.

\section{METODE}

Penelitian ini dilaksanakan dengan metode survey analitik dengan desain cross sectional. Variabel independen dalam penelitian ini adalah tingkat pengetahuan WUS tentang kanker serviks dan variabel dependen nya adalah sikap terhadap pemeriksaan pap smear. Penelitian ini dilakukan pada tanggal 16, 23 dan 27 April 2017, di Dusun Pancuran, Terong, Bantul. Populasi dalam penelitian ini adalah seluruh wanita usia subur (WUS) di Dusun Pancuran, Terong, Bantul yang berusia 15-49 tahun baik yang berstatus kawin maupun yang belum kawin atau janda dan berjumlah 191 orang. Metode pengambilan sampel dalam penelitian ini menggunakan teknik simple random sampling dengan besar sampel minimal 68 responden dan dalam penelitian ini didapatkan 90 responden. Penelitian ini menggunakan jenis data primer. Alat untuk mengukur atau mengumpulkan data adalah kuesioner yang sebelumnya telah dilakukan uji validitas dan reabilitas di Dusun Gulon, Bantul. Analisis yang digunakan adalah analisis univariabel, analisis bivariabel menggunakan uji Chi-Square, dan uji keeratan hubungan menggunakan Koefisien Kontingency.

\section{HASIL}

Karakteristik responden mengenai pendidikan, pengalaman pap smear, dan status ekonomi.

Tabel 1. Distribusi Frekuensi Responden

berdasarkan karakteristik pada WUS di Dusun Pancuran Bantul Tahun 2017

\begin{tabular}{|c|c|}
\hline Karakteristik & $\begin{array}{l}\text { Frekuensi Persentase } \\
\text { (f) }\end{array}$ \\
\hline \multicolumn{2}{|l|}{ Pendidikan } \\
\hline Dasar (SD, SMP) & 72 \\
\hline Menengah (SMA) & 20 \\
\hline $\begin{array}{l}\text { Tinggi (diploma, } \\
\text { sarjana, pasca sarjana) }\end{array}$ & 0 \\
\hline \multicolumn{2}{|l|}{ Pengalaman Pap smear } \\
\hline Pernah & 18 \\
\hline Belum pernah & 82 \\
\hline \multicolumn{2}{|l|}{ Status ekonomi } \\
\hline <UMK (Rp 1.404.760) & 69 \\
\hline$=U M K(\operatorname{Rp~1.404.760)~}$ & 31 \\
\hline Jumlah & 100 \\
\hline
\end{tabular}

Hasil penelitian pada tabel 1 menunjukkan tingkat pendidikan responden paling banyak adalah lulusan pendidikan dasar (SD/SMP) sebanyak 72 responden $(80 \%)$, pengalaman sebanyak 74 responden $(82 \%)$ belum pernah melakukan pemeriksaan pap smear, dan sebagian besar responden status ekonomi masih $<$ UMK Bantul (Rp 1.404.760) sebanyak 62 responden (69\%).

Tabel 2. Distribusi Frekuensi Tingkat Pengetahuan WUS tentang Kanker Serviks di Dusun Pancuran, Bantul Tahun 2017

\begin{tabular}{ccc}
\hline $\begin{array}{c}\text { Tingkat } \\
\text { pengetahuan }\end{array}$ & $\begin{array}{c}\text { Frekuensi } \\
\text { (f) }\end{array}$ & $\begin{array}{c}\text { Persentase } \\
\text { (\%) }\end{array}$ \\
\hline Baik & 43 & 48 \\
Cukup & 30 & 33 \\
Kurang & 17 & 19 \\
\hline Jumlah & $\mathbf{9 0}$ & $\mathbf{1 0 0}$ \\
\hline
\end{tabular}

Tabel 2 menunjukkan bahwa sebagian besar responden berpengetahuan baik sebanyak 43 responden (48\%).

Tabel 3. Distribusi Frekuensi Sikap WUS Terhadap Pemeriksaan Pap Smear Di Dusun Pancuran Bantul Tahun 2017

\begin{tabular}{ccc}
\hline Sikap & $\begin{array}{c}\text { Frekuensi } \\
\text { (f) }\end{array}$ & $\begin{array}{c}\text { Persentase } \\
\text { (\%) }\end{array}$ \\
\hline Mendukung & 35 & 39 \\
Tidak mendukung & 55 & 61 \\
\hline Jumlah & $\mathbf{9 0}$ & $\mathbf{1 0 0}$ \\
\hline
\end{tabular}

Tabel 3 menunjukkan bahwa sebagian besar responden bersikap tidak mendukung sebanyak 55 responden (61\%). 
Tabel 4. Tabel Silang Tingkat Pengetahuan dengan Sikap WUS

Di Dusun Pancuran Bantul Tahun 2017

\begin{tabular}{|c|c|c|c|c|c|c|c|c|}
\hline \multirow{3}{*}{$\begin{array}{l}\text { Tingkat Pengetahuan } \\
\text { tentang Kanker Serviks }\end{array}$} & \multicolumn{4}{|c|}{$\begin{array}{c}\text { Sikap Terhadap } \\
\text { Pemeriksaan Pap } \\
\text { Smear }\end{array}$} & \multirow{2}{*}{\multicolumn{2}{|c|}{ Jumlah }} & \multirow{2}{*}{$\begin{array}{c}\mathrm{P} \\
\text { value }\end{array}$} & \multirow[t]{3}{*}{ CC } \\
\hline & \multicolumn{2}{|c|}{$\begin{array}{c}\text { Tidak } \\
\text { mendukung }\end{array}$} & \multicolumn{2}{|c|}{ Mendukung } & & & & \\
\hline & $f$ & $\%$ & $f$ & $\%$ & $f$ & $\%$ & & \\
\hline Kurang & 17 & 94.4 & 1 & 5.6 & 18 & 100 & & \\
\hline Cukup & 25 & 83.3 & 5 & 16.7 & 30 & 100 & 0.000 & 0.504 \\
\hline Baik & 13 & 31.0 & 29 & 69.0 & 42 & 100 & & \\
\hline Jumlah & 55 & 61.1 & 35 & 38.9 & 90 & 100 & & \\
\hline
\end{tabular}

Tabel 4 menunjukkan bahwa sebagian besar responden mempunyai pengetahuan baik dengan sikap mendukung pemeriksaan pap smear sebanyak 29 responden $(69 \%)$ dan sikap tidak mendukung sebanyak 13 responden (31\%). Data diolah dengan uji statistika chi-square dan diperoleh nilai $p$-value $=$ $0.000(<0.05)$. Hal ini menujukkan bahwa secara statistik ada hubungan antara tingkat pengetahuan tentang kanker serviks dengan sikap pemeriksaan pap smear. Hasil uji statistik koefisien kontingency yaitu sebesar $0.504(0.4 \mathrm{sd}<0.6)$ hal ini menunjukkan bahwa keeratan hubungan tingkat pengetahuan dengan sikap terhadap pemeriksaan pap smear yaitu sedang.

\section{PEMBAHASAN}

Hasil karakteristik responden penelitian di Dusun Pancuran, Bantul tahun 2017, yaitu sebagian besar responden tingkat pendidikan nya adalah pendidikan dasar (SD/SMP), yaitu sebanyak 78 responden $(72 \%)$. Menurut Notoatmodjo, pendidikan adalah suatu kegiatan atau proses pembelajaran untuk mengembangkan atau meningkatkan kemampuan tertentu ${ }^{8}$. Pendidikan seseorang berpengaruh terhadap pengetahuan seseorang. Pada umumnya semakin tinggi tingkat pendidikan seseorang semakin baik pula pengetahuannya, begitu pula dengan pendidikan yang rendah berkontribusi terhadap seberapa besar pengetahuan seseorang. Namun, perlu ditekankan bahwa seseorang yang berpendidikan rendah tidak berarti mutlak berpengetahuan rendah pula. Hasil penelitian pengetahuan responden menunjukkan bahwa sebagian besar responden sudah berpengetahuan baik sebanyak 42 responden (46.7\%), pengetahuan cukup sebanyak 30 responden (33.3\%), dan pengetahuan kurang sebanyak 18 responden (20\%).

$\mathrm{Hal}$ ini sejalan dengan penelitian yang dilakukan oleh Sinta Oktavyany, pengetahuan sebagian besar responden tentang kanker serviks berpengetahuan baik dan sebagian besar karakteristik pendidikan nya adalah menengah (SMA), dan dalam hal ini, tidak menutup kemungkinan seseorang tersebut memperoleh pengetahuan dari faktor lain, tidak hanya dari faktor pendidikan saja ${ }^{9}$. Faktor-faktor yang mempengaruhi pengetahuan salah satunya, yaitu usia, pengalaman, pendidikan, dan status ekonomi ${ }^{6}$.

Sebagian besar pengalaman responden belum pernah melakukan pap smear sebanyak 74 responden (82.2\%). Peneliti juga menanyakan alasan responden tidak melakukan pap smear, dengan alasan paling banyak yaitu takut sebanyak 45 responden (60.8\%), dengan alasan malu sebanyak 18 responden $(24.3 \%)$, dengan alasan tidak tahu sebanyak 7 responden (9.5\%), dengan alasan belum menikah sebanyak 4 responden (5.4\%). Hal ini mendukung penelitian Shina Oranratanaphan alasan terbanyak tidak melakukan pap smear karena takut sebanyak $27.6 \%$ dan malu $26.3 \%$ dari total 78 responden ${ }^{10}$.

Pengalaman merupakan sumber pengetahuan, dan pengalaman itu adalah suatu cara memperoleh kebenaran pengetahuan. Oleh sebab itu, pengalaman dapat digunakan sebagai upaya untuk memperoleh pengetahuan. Hal ini dilakukan dengan cara mengulang kembali pengalaman yang diperoleh dalam memecahkan permasalahan yang dihadapi pada masa lalu, dan ada kaitannya dengan pengaruh pengalaman sendiri maupun pengalaman dari orang lain $^{6}$. Pengalaman juga dapat menjadi dasar pembentukan sikap apabila pengalaman tersebut meninggalkan kesan yang kuat dan pernah melakukan hal tersebut. Apa yang telah dan sedang kita alami akan ikut membentuk dan mempengaruhi penghayatan kita terhadap stimulus sosial. Tanggapan akan menjadi salah satu dasar terbentuknya sikap. Untuk dapat mempunyai tanggapan dan penghayatan, seseorang harus mempunyai pengalaman yang berkaitan dengan objek psikologis. Apakah penghayatan tersebut akan membentuk sikap yang mendukung ataukah sikap yang tidak mendukung.

Middlebrook (1974) dalam Azwar mengatakan bahwa tidak adanya pengalaman sama sekali dengan suatu objek psikologis cenderung akan membentuk sikap tidak mendukung terhadap objek tersebut ${ }^{7}$. Melihat dari hasil penelitian ini sejalan dengan teori tersebut. Sebagian besar pengalaman responden 
belum pernah melakukan pap smear sebanyak 74 responden $(82.2 \%)$, dan sikap responden terhadap pemerikaan pap smear juga sebagian besar tidak mendukung yaitu sebanyak 55 responden $(61.1 \%)$. Hal ini juga didukung dengan penelitian dari Ni Ketut Martini menunjukkan bahwa sikap terbukti berhubungan dengan tindakan pemeriksaan pap smear $^{11}$. Hasil penelitian ini juga mendukung penelitian Ranabhat, S., Dhungana, G., Neupane, M., Shrestha R., dan Tiwari, M. yaitu ada hubungan sikap tentang pap smear untuk melakukan tes pap smear ${ }^{12}$.

Penjelasan diatas menunjukkan bahwa pengalaman mempengaruhi seseorang untuk pengambilan keputusan yang teliti dan beralasan yang membentuk suatu niat kepada objek tertentu. Memperhatikan hal tersebut, pembentukan sikap tidak hanya dipengaruhi oleh 1 faktor saja, tetapi dipengaruhi oleh beberapa faktor, seperti pengalaman, kebudayaan, pengaruh orang lain yang dianggap penting, media massa, institusi atau lembaga pendidikan dan lembaga agama, pengetahuan, serta faktor emosi dalam diri individu? ${ }^{7}$.

Pengetahuan juga didukung salah satunya oleh faktor status ekonomi seseorang tersebut. Status ekonomi sebagian besar WUS di Dusun Pancuran, Bantul berpenghasilan <UMK Bantul (Rp 1.404.760), yaitu sebanyak 62 responden (68.9\%). Konsekuensi akibat pendapatan yang rendah mempengaruhi kebutuhan primer maupun sekunder seseorang ${ }^{6}$. Seseorang yang mempunyai pendapatan lebih akan lebih mampu untuk memenuhi kebutuhan sekunder nya, tetapi hal tersebut juga tidak mutlak karena faktor tersebut.

Hasil penelitian uji statistika tingkat pengetahuan kanker serviks dengan sikap terhadap pemeriksaan pap smear pada WUS di Dusun Pancuran Bantul tahun 2017 diketahui bahwa nilai $p$-value pada uji ChiSquare sebesar 0.000 sedangkan taraf kesalahan yang ditentukan adalah 5\% (0.05). Hal ini menunjukkan bahwa ada hubungan antara pengetahuan kanker serviks dengan sikap terhadap pemeriksaan pap smear dengan keeratan hubungan sedang (0.504). Hal ini sesuai dengan teori yang menyatakan bahwa seseorang mampu mengorganisasikan dan menginterprestasikan berbagai macam informasi yang ia terima, lalu setelah mengetahui informasi tersebut, proses selanjutnya mereka kemudian bersikap terhadap objek tersebut. Pengetahuan memegang peranan penting dalam penentuan sikap ${ }^{8}$.

\section{KESIMPULAN}

Berdasarkan hasil penelitian dan pembahasan pada penelitian ini dapat ditarik kesimpulan sebagai berikut:

1. Karakteristik WUS Di Dusun Pancuran Bantul sebagian besar berpendidikan dasar (SD/SMP), pengalaman sebagian besar belum pernah melakukan pemeriksaan pap smear, dan status ekonomi berpenghasilan <UMK Bantul.

2. Tingkat pengetahuan tentang kanker serviks pada WUS Di Dusun Pancuran Bantul sebagian besar dalam kategori baik.

3. Sikap terhadap pemeriksaan pap smear pada WUS Di Dusun Pancuran Bantul sebagian besar tidak mendukung.

4. Ada hubungan tingkat pengetahuan tentang kanker serviks dengan sikap terhadap pemeriksaan pap smear pada WUS Di Dusun Pancuran Bantul dengan keeratan hubungan sedang.

\section{SARAN}

Bagi bidan Puskesmas Dlingo 2 disarankan untuk memberikan penjelasan dan informasi lebih sering tentang kanker serviks sebagai upaya promotif dan preventif dalam deteksi dini kanker serviks. Bagi wanita usia subur disarankan untuk mencari informasi tambahan mengenai kanker serviks dan beserta deteksi dini lainnya. Bagi peneliti selanjutnya disarankan untuk membuktikan ulang hipotesis dengan menambah sampel.

\section{DAFTAR PUSTAKA}

1. PUSDATIN. Situasi Penyakit Kanker. Jakarta: Pusat Data dan Informasi; 2015.

2. Riset Kesehatan Dasar (Riskesdas). Badan Penelitian dan Pengembangan Kesehatan Kementerian RI tahun 2013. Jakarta: Kementrian RI; 2013. [Diunduh pada 2016, 10 Desember] di: http://www.depkes.go.id/resources/download/gen eral/Hasil\%20Riskesdas\%20 2013.pdf

3. Dinkes DIY. Profil Kesehatan Provinsi DIY. Yogyakarta: Dinkes Provinsi DIY; 2016.

4. Komite Penanggulangan Kanker Nasional. Draft Pedoman Nasional Pelayanan Kedokteran Kanker Serviks. Jakarta: Kementrian Kesehatan RI; 2015. [Diunduh pada 2017, 10 Januari] di: h t t p : / / k a n k e r.kemkes.go.id / guidelines_read.php?id=1\&cancer=3

5. Birotapem Setda DIY. Jumlah Penduduk Kecamatan Dlingo Menurut Jenjang Pendidikan Semester I 2016. DIY : Biro Tata Pemerintahan Setda DIY; 2017. [Diunduh pada 2017, 10 Februari] di: http://kependudukan.jogjaprov. go.id/olah.php?module $=$ statistik $\&$ periode $=5 \&$ jenis data=penduduk\&berdasarkan=pendidikan \&prop= $34 \& k a b=02 \& k e c=11$

6. Notoatmodjo, S. IImu Perilaku Kesehatan. Jakarta: Rineka Cipta; 2010.

7. Azwar, S. Sikap Manusia Teori dan Pengukurannya. Yogyakarta: Pustaka Pelajar; 
2013.

8. Notoatmodjo, S. Promosi Kesehatan dan Perilaku Kesehatan. Jakarta: Rineka Cipta; 2014.

9. Oktavyany, S., Yusriana, C., dan Ratnaningsih, D. Hubungan Tingkat Pengetahuan tentang Kanker Serviks dengan Sikap Terhadap Pemeriksaan Pap Smear Pada PUS Di Puskesmas Semanu Gunungkidul. Jurnal Permata Indonesia. 2015; 6(2): 57-67. [Diunduh pada 2017, 7 Mei] di: .ac.id/wp-content/uploads/2016/01/06.-JurnalPI_Sinta-Chinthia-Dwi.pdf.

10.Oranratanaphan, S., Amatyakul, P., Iramaneerat, K., dan Srithipayawan, S. Knowledge, Attitudes and Practices about the Pap Smear among Medical Workers in Naresuan University Hospital. Asian Pacific Journal of Cancer Prevention. 2010;11(1). [Diunduh pada 2017, 7 Mei] di: http://www.apocpcontrol.net/paperfile/issue_abs/ Volume 11 _No6/c\%2001727.
30\%2011.28\%20Shina\% 20Oranratanaphan.pdf

11. Martini, Ni Ketut. Hubungan Karakteristik, Pengetahuan dan Sikap Wanita Pasangan Usia Subur Dengan Tindakan Pemeriksaan Pap Smear Di Puskesmas Sukawati II; 2013. [Diunduh pada $2016, \quad 10$ D e s e m be r ] d i : http://www.pps.unud.ac.id/thesis/detail-778hubungan-karakteristik-pengetahuan-dan-sikapwanita-pasangan-usia-subur-dengan-tindakanpemeriksaan-pap-smear--di-puskesmassukawatiii.html

12.Ranabhat, S., Dhungana, G., Neupane, M., Shrestha, R., dan Tiwari, M. Pap Smear Coverage And Effect Of Knowledge And Attitude Regarding Cervical Cancer On Utilization Of The Test By Women In Udayapur District Of Nepal. Journal of Chitwan Medical College. 2014; 4(10): 31-35. [Diunduh pada 2016, 10 Desember] di:ww.jcmc.cmc.edu. 